\title{
ナイトレニウムイオン $-\mathbf{N}-\mathbf{X}$ 結合のヘテロリシス
}

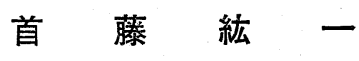

Nitrenium Ions-The Heterolysis of N-X Bonds

Koichi SHUDO*

ヒドロキシルアミン類，八ロアミン類を含む $\mathrm{N}-\mathrm{X}$ 結 合 $(\mathrm{X}=\mathrm{O}, \mathrm{N}, \mathrm{Cl}, \mathrm{Br} \text { 等 })^{1)}$ の解離の様式は, その結合のラ ジカル的開裂〔1】式とへテロリシスに分けられる。後者 はさらに電子対が窒素原子に残る場合〔2〕式と電子対が X原子に残る〔3〕式とに分けられる。〔3〕式で生成する

$$
\begin{aligned}
& >\ddot{\mathrm{N}}-\mathrm{X} \longrightarrow \mathrm{i} \cdot+\cdot \mathrm{X} . . \\
& >\ddot{\mathrm{N}}-\mathrm{X} \longrightarrow \ddot{\mathrm{N}}:{ }^{\ominus}+\mathrm{X}^{\oplus . .} \\
& >\ddot{\mathrm{N}}-\mathrm{X} \longrightarrow \mathrm{\textrm {N }} \oplus+: \mathrm{X}^{\ominus} . .
\end{aligned}
$$

$>\ddot{\mathrm{N}}^{\oplus}$ (1) は二価の窒素陽イオン (positively charged divalent nitrogen) であり, ナイトレン (nitrene, $-\ddot{\mathrm{N}}$ : (2)）がアルキル化され，あるいはプロトンが付加して 陽電荷を持ったものと見なすことができ，ナイトレニウ ムイオン (nitrenium ion) ${ }^{2,3)}$ と呼ぶ。また電子久損窒 素 (electron deficient nitrogen) ${ }^{1 b)}$ という名称は性!格 をよく表わしている。

$$
>\ddot{\mathrm{N}}^{\oplus} \text { or }>\dot{\mathrm{N}}^{\oplus}
$$

$-\ddot{\mathrm{N}}$ or $-\dot{\mathrm{N}}$.

(2)
カルボニウムイオン (3) に対して, ナイトレニウムイ オンは二価であり二個の非結合電子を持つ点が最も異な り,また (3) は安定な陽イオンとして存在し得るのに反 し, free のナイトレニウムイオンは存在の可能性は示 されているが4)，陽電荷が窒素上に局在化したナイトレ ニウムイオンは非常に活性と思われ, 反応中にどの程度 の関与があるか注個々の反応について大巾に異なるとみ られる。ここでは $\mathrm{N}-\mathrm{X}$ 結合が〔3】式に基づき $\mathrm{X}^{\ominus}$ 解離する場合, 窒素原子は少なくとも部分的には陽電荷 をもち，ナイトレニウムイオン性を有するとの考えか ら，N-X 結合のヘテロリシス一般について，反応を中 心とし近年の進歩を考えていきたい。

* 東京大学薬学部

* Faculty of Pharmaceutical Sciences, University of Tokyo
I. ハロアミンおよびヒドロキシルアミン

八ロアミンおよびヒドロキシルアミン O-スルホン酸 $\left(\mathrm{H}_{2} \mathrm{NOSO}_{3} \mathrm{H}\right)$ はそれぞれ $\mathrm{CH}_{3} \mathrm{Br}$ や $\mathrm{CH}_{3} \mathrm{OTs}$ に対応す る窒素化合物であり, 炭素の場合と同様に求核試薬 $\mathrm{Y}^{-}$ と $\mathrm{S}_{\mathrm{N}} 2$ 反応を起こす ${ }^{5,6)}([4]$ 式)。この反応は 1,1 -二置

$$
\begin{aligned}
\mathrm{Y}^{-}+\mathrm{NH}_{2}-\mathrm{X} & \longrightarrow \mathrm{Y}-\mathrm{NH}_{2}+\mathrm{X}^{-} . \\
\mathrm{X} & =\text { halogen, } \mathrm{OSO}_{3} \mathrm{H},{ }^{+} \mathrm{OH}_{2} \\
\mathrm{Y} & =\mathrm{RO}, \mathrm{RR}^{\prime} \mathrm{N}, \mathrm{RS}
\end{aligned}
$$

換ヒドラジンや O-アルキルヒドロキシルアミンの合成 法であるが， $\mathrm{S}_{\mathrm{N}} 2$ 反応に期待される速度式を与える。 三級アミンとクロラミンとの反応も二次反応であるが, 芳香族アミンの $\mathrm{N}$-アミノ化の速度論的研究はない。オ キシムとクロラミンあるいはヒドロキシルアミン O-ス ルホン酸とからジアゾ化合物を合成する反応〔5】式も類 似の求核反応とみられる

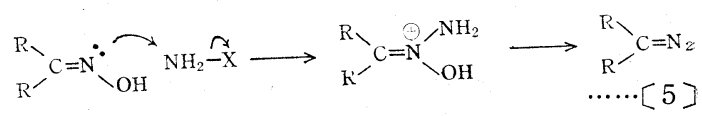

O-メシチレンスルホニルヒドロキシルアミン (4) お よび関連化合物がアミノ化剂として有用であることが示 され，反応機構および合成反応への応用が期待される ${ }^{8)}$ 。<smiles>COc1ccc(C)c(C)c1</smiles>

\section{II. アルキルナイトレニウムイオン}

1. 求核置換反応 $\mathrm{N}$-置換基のない八ロアミンや ヒドロキシルアミン誘導体で $\mathrm{S}_{\mathrm{N}} 2$ 的反応が認められる

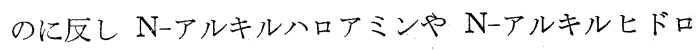
キシルアミンで窒素上での求核置換反応が認められるこ とは少ない。ジアルキルクロラミンと窒化ナトリウムを 塩化メチレン中で反応させるとジアルキルアミンアジド 
が得られる ([6]式 $)^{9)}$ 。この反応は反応条件から考えて

$$
\mathrm{R}_{2} \mathrm{NCl}+\mathrm{NaN}_{3} \stackrel{\mathrm{CH}_{2} \mathrm{Cl}_{2}}{\longrightarrow} \mathrm{R}_{2} \mathrm{~N}-\mathrm{N}_{3}+\mathrm{NaCl}
$$

$\mathrm{S}_{\mathrm{N}} 2$ 反応とみられる。

ジアジリジンはホルマリンとアミンの付加体を次亜塩 素酸塩で酸化すると得られるが ([7]式)，これは分子内 でのアミンによる求核反応とみることができる10)。

$$
\mathrm{CH}_{2} \mathrm{O}+2 \mathrm{RNH}_{2} \longrightarrow \mathrm{H}_{2} \mathrm{C}^{\prime}{ }^{\prime}{ }^{\mathrm{NHR}}
$$

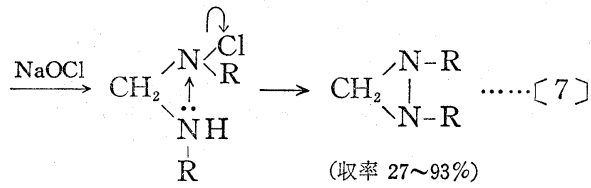

アルキルクロラミンやアルキルヒドロキシルアミンに よる芳香環のアミノ化反応が知られているが5)，多くは ラジカル的である。しかし酸触媒下でのジアルキルアミ ノ化の場合に $\mathrm{R}_{2} \mathrm{~N}^{+}$が関与する可能性も考光られてい る $^{11}$ 。

2. 水素引き抜き反応 カルボニウムイオンは transannular な位置にある水素を hydride の形で引き 抜く ${ }^{12)}$ 。ナイトレニウムイオンでの類似の反忘が Edwa$\operatorname{rds}$ らにより報告された ${ }^{13)}$ 。中員環の二級アミン (5) ま たは二級アミドを水性ジオキサン中で銀塩の存在下に反 応させると二環性化合物 (6) が得られる。こうして Nクロルアザシクロノナン $(\mathrm{n}=1)$ は室温下収率 $68 \%$ で インドリチジン $(6, \mathrm{n}=1)$ を与える。環が 8 ない 10<smiles>ClN1CCCCCCC1</smiles>

(5)

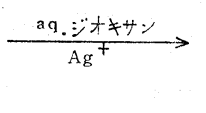

$$
\text { 收率 } \begin{array}{rr}
\mathrm{r}=0 & 16 \% \\
1 & 68 \%
\end{array}
$$

員環になると収率は悪くなる13)。6 員環では原料アミン

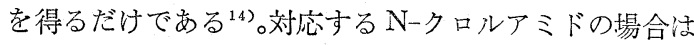
$80^{\circ} \mathrm{C}$ に加温を要し，汃収率も悪くなる (5 13\%)。 これらの反応は $\mathrm{N}-\mathrm{Cl}$ 結合の加溶媒分解でできたナイ トレニウムイオン (7) による transannular な位置の hydride $\left(\mathrm{H}^{-}\right)$引き抜きを経由する反店 (a) と考えられ ている ${ }^{13)}$ が，後に述べような三重項状態のナイトレニ ウムイオン (8) による水素原子の引抜きによる経路 (b) も考えられる(図 1)。

この反応は不活性のメチレンの官能化という点で重要 であり，収量は低いが N-メチルグラナタニン (9) の合 成 ${ }^{13)}$ に応用されている。また類似の反応がステロイドア

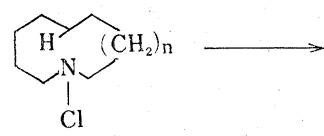

(5)

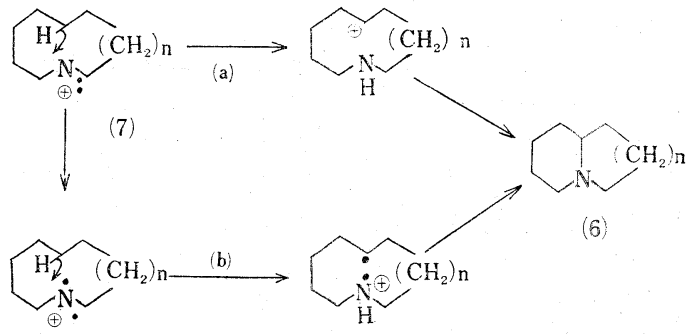

(8)

図 1

ルカロイドの合成 $(10 \rightarrow 11)$ でも利用されている ${ }^{15}$ 。
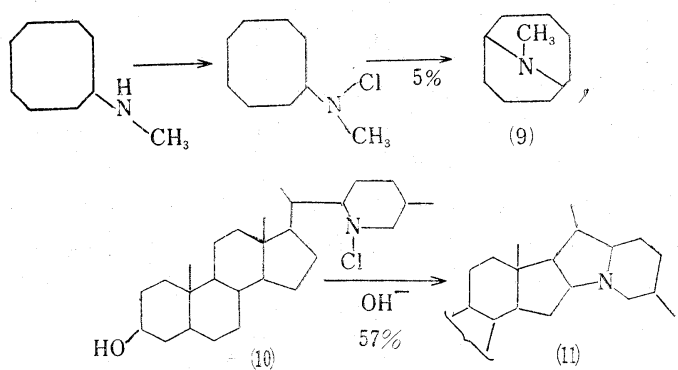

3. アルキル基の転移 ナイトレニウムイオン中心 への単純なアルキル基の転移はアルキルアジドの酸分解 （〔8】式)でホルマリンと炭素の一つ少ないアミンの生成 $\mathrm{RCH}_{2} \mathrm{~N}_{3} \stackrel{\mathrm{H}^{+}}{\longrightarrow} \mathrm{RCH}_{2} \mathrm{NHN}=\mathrm{N}^{+} \longrightarrow \mathrm{R}-\mathrm{CH}_{2} \stackrel{+}{\mathrm{N}} \mathrm{H} \cdots \mathrm{N}_{2}$

$$
\stackrel{-\mathrm{N}_{2}}{\longrightarrow} \mathrm{CH}_{2}=\stackrel{+}{\mathrm{N}} \mathrm{HR} \underset{\mathrm{H}^{+}}{\stackrel{\mathrm{H}_{2} \mathrm{O}}{\longrightarrow}} \mathrm{CH}_{2} \mathrm{O}+\mathrm{RNH}_{2}+\mathrm{H}^{+} \ldots \ldots[8]
$$

する反応で考えられる ${ }^{1 \mathrm{~b}, 17)}$ 。トリブチルカルビナミンか

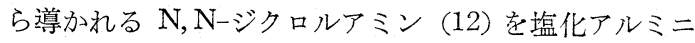
ウムで処理すると窒素原子上へブチル基の転移が起こ り, 加水分解を経てジーn-ブチルケトン (13) と $n$-ブチ ルアミン (14) が生成する ([9]式 $)^{16)}$ 。

$(n-\mathrm{Bu})_{3} \mathrm{CNCl}_{2} \underset{-\mathrm{Cl}^{-}}{\stackrel{\mathrm{AlCl}_{2}}{\longrightarrow}}(n-\mathrm{Bu})_{3} \mathrm{CNCl}$

$$
\begin{aligned}
& \longrightarrow(n-\mathrm{Bu})_{2} \stackrel{+}{\mathrm{Cl}} \mathrm{N}(n-\mathrm{Bu}) \stackrel{+\mathrm{Cl}-}{\rightleftarrows}(n-\mathrm{Bu})_{2} \stackrel{\mathrm{Cl}}{\mathrm{C}}-\mathrm{Cl}(\mathrm{N}-\mathrm{Bu}) \\
& \mathrm{OH} \\
& \stackrel{\mathrm{H}_{2} \mathrm{O}}{\longrightarrow}(n-\mathrm{Bu})_{2} \mathrm{C} N H(n-\mathrm{Bu}) \\
& \longrightarrow(n-\mathrm{Bu})_{2} \mathrm{CO}+n-\mathrm{BuNH}_{2}
\end{aligned}
$$

Gassman らは数年来この種の研究を続けているが, その中には合成法としても発展の期待される反応も多 くまたナイトレニウムイオン反応機構の研究も彼らの 
グループに負らところが大きい。最初の 報告は 1966 年, イソキヌクリジンの転 移反応である18)。<smiles>C1CC2CC1CN2</smiles>

(15)

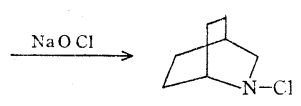

(16)

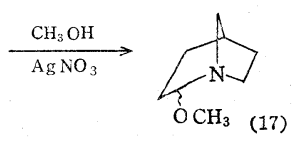

イソキヌクリジン (15) から容易に得 られるクロラミン (16) をメタノール中 硝酸銀の存在下で還流すると，60\%の収 率で 2-メトキシー1-アザビシクロ [3.2. 1】オクタン (17) を与える。

この種の反応のさら詳しい研究はメチル置換アザビ シクロ化合物で行なわれた ${ }^{19)}$ 。4, 7,7-トリメチルー2-ク ロル-2-アザビシクロ [2.2.1]ヘプタン (18) のメタノー ル中の加溶媒分解は䎐移体 (19), (20) および原料アミン （21）をそれぞれ 59，20，7\% 收率で与える。銀塩の存 在下では反応は 1000 倍程度促進され，同一生成物をそ れぞれ $77 ， 8 ， 4 \%$ の収率で与光る。これらの反応は $\mathrm{N}-\mathrm{Cl}$ の加溶媒 分解で生成したナイトレニウムイオン (22) への $\mathrm{C}_{1}-\mathrm{C}_{6}$ 結合の転移によってできたカルボニウ ムイオン (23) と求椟試薬との反応とみられ, $\mathrm{CH}_{3} \mathrm{OH}$ の付加 (反応条件下での $19 \rightarrow 20$ の反応注遅い) や $\mathrm{Ag}^{+}$ による速度増加はこの反応機構を支持する。実際の遷移 状態はイオン対 (24) のようなもので説明される(図2)。

同様の転移反応は非置換の 2 -アザノルボルナン

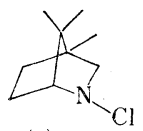

(18)

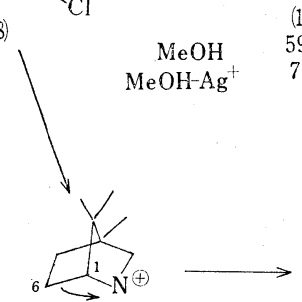

(22)

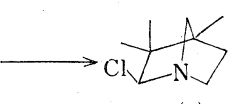

$(19)$
$59 \%$

77

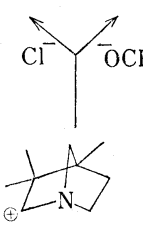

(23)
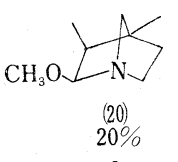

8 $\mathrm{CH}_{3}$

図 2

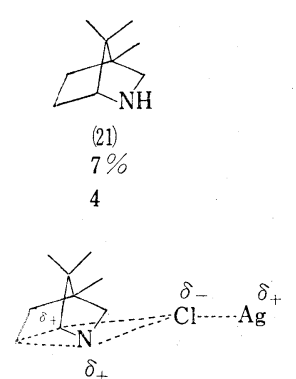

(24)

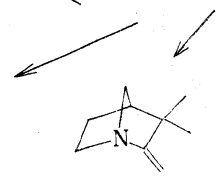

(28)

$13 \%$

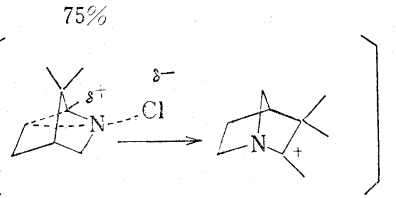

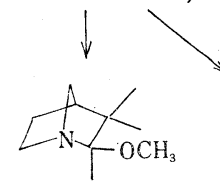

(29)

$64 \%$

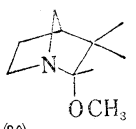

(30)
図 3

表 1 亿示寸 (18), (25), (26) の加溶媒 分解の速度パ ラメーターは対応するカルボニウムイオンの生成 ${ }^{21)}$ の場 合とくらべ矛盾しないるのであり ${ }^{3,20)}, \mathrm{N}-\mathrm{Cl}$ 結 合のへ

表 1 クロラミンのメタノール中加溶媒分解の速度

\begin{tabular}{|c|c|c|c|}
\hline & $k_{\text {rel }}\left(50^{\circ} \mathrm{C}\right)$ & $\Delta H^{*}$ & $\Delta S^{*}$ \\
\hline & 1 & 22.3 & -12.7 \\
\hline & 1.7 & 23.8 & -6.7 \\
\hline & 23 & 22.6 & -5.4 \\
\hline (26) & & & \\
\hline
\end{tabular}

テロリシス機構を支持する。

このようなナイトレニウムイオン中心 を生成するために注 $\mathrm{N}-\mathrm{Cl}$ 結合のほか $\mathrm{N}-\mathrm{Br}, \mathrm{N}-\mathrm{OT}$ s の加溶媒分解や $\mathrm{N}-\mathrm{NH}_{2}$ の脱アミノ化などが考えられる。(18)に 対忘する $\mathrm{N}-\mathrm{Br}$ 化合物 (31) は不安定な C-ブロミド (32) を経て 70\% の收率で (20)を与える ${ }^{20)}$ 。同じく (26) に対応す

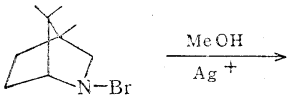

(31)

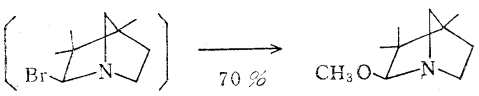

(32)

(20) 
る N-プロミドからは $(27 ; 10 \%),(28 ; 11 \%),(29 ; 29$ $\pm 10)$ ，および $(30 ; 38 \pm 10 \%)$ を生成する ${ }^{20,22) 。}$

スルホン酸エステルも脱離基として有効なはずであ り，Biehler らにより ${ }^{23) ， ま た ~ G a s s m a n ~}{ }^{24)}$ らにより支 持された。窒素の $\alpha$-位に電子吸引基 $\left(\mathrm{CN}, \mathrm{COOCH}_{3}\right)$ を有する，二級ヒドロキシルアミンの $p$-トルエンスル ホン酸エステル $(33,34)$ は安定であるが，水性ジオキサ ン中で容易に転移を起こし，それぞれ (35) および (36) を 42〜 75\% の収率で得ることができる ${ }^{23) 。 ~}$

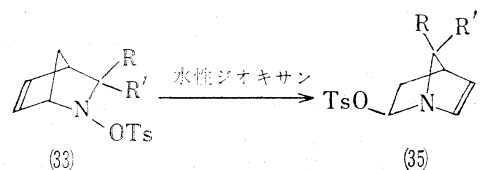

(33)

(35)

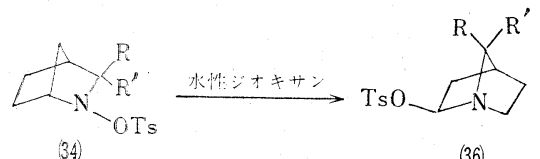

34

(36)

電子吸引基を持たない場合はスルホン酸エステルは取 り出せないが，対応する転移反応を起こして（37）から は (38) が得られる24)。

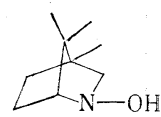

(37)
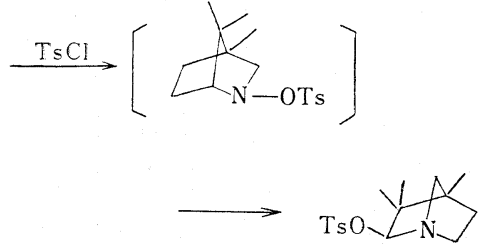

(38)
ヒドラジン類のジアゾ化反応でナイトレニウムイオン ができるかどうかは一級アミンのジアゾ化反応やアジド 類の酸分解との関連から興味がもたれる。N-アミノ化 合物 (39) を亜硝酸イソアミルでメタノール中ジアゾ化 すると，21\%の（20）と67\%の (21) を生成する ${ }^{25) 。 ~}$ (20) の生成はクロラミンやトシラートの加溶媒分解に よる生成物であり，脱アミノ化でもナイトレニウムイオ ン中間体 (22) が関与している。ここで (21) が大量に 生成しているのは，反応中発生するガス中に $\mathrm{N}_{2} \mathrm{O}$ が含 まれることから，全く別の過程による。同じく（40）の 脱アミノ化も進行し (27)，(28)，(29)，(30)を与える。

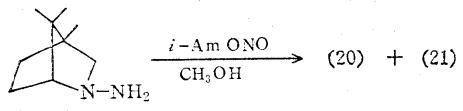

(39)

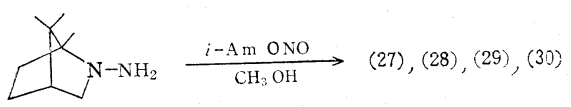

(40)

Kovacic らはジクロルアミン類での転移反応を報告し ている ${ }^{26,27) 。}$

図 4 に示す反応は塩化アルミニウム存在下でかなり複 雑であるが，ナイトレニウムイオン経由の反応として説 明されており，收率も複雑な反応の割には良い。

4. 小員環化合物 シクロプロピルカルボニウムイ オン（41）との比較からシクロプロピルナイトレニウム

26) $A_{-\mathrm{Cl}} \underset{\mathrm{AlCl}_{3}}{\longrightarrow} \mathrm{N}_{\mathrm{NCl}_{2}}^{\stackrel{-\mathrm{Cl}^{-}}{\longrightarrow}}$

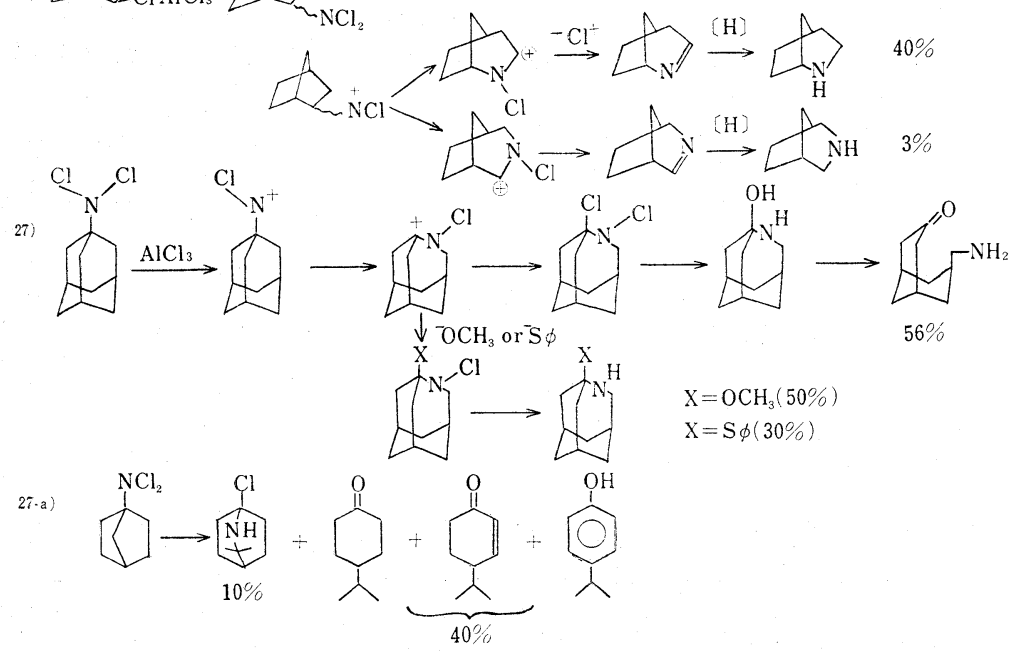

図 4 
イオン（42）も環の搪大を起こすと期待 される。

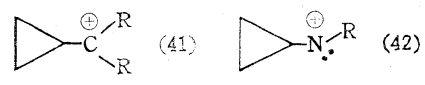

N-クロラミン (43) をメタノール中銀 塩存在下に分解すると $(44 ; 85 \%)$ と
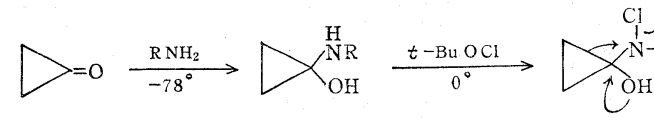

(53)

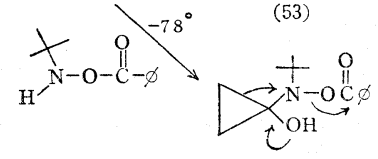

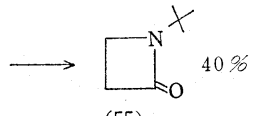

(55)

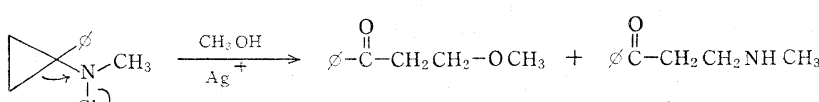

(44)

(43) C17

(

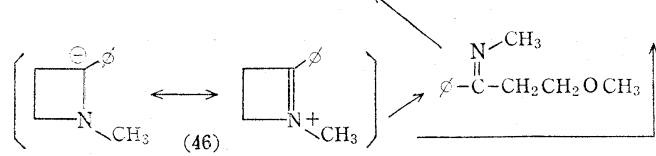

(45；7\%) を与える28)。これらはアゼチジニウム塩 (46) を経て生成したものと思える。四員環 (47) でも環の拡 大を起こし還元を経て五員環アミン (48)を与える29)。

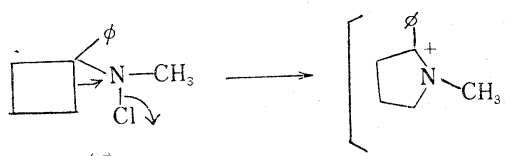

(47)<smiles>CCCCCCCC1CCN(C)C1C</smiles>

(48)

クロル化の後，アセトニトリル中硝酸銀で処理 するとシクロプロパノンから計算しておよそ $50 \%$ の収率で N-アルキルート-ラクタム (54) がえられる322。

O-ベンゾイル-N-t-ブチルヒドロキシルア ミンとシクロプロパノンとの反応は安息香酸を 脱離して $\mathrm{N}-t$-ブチル- $\beta-$ フクタム $(55)$ を $40 \%$ 収率で与える ${ }^{32)}$ 。こ机らの反応はいずれもナイト レニウムイオン (42) の関与する反応であり $\beta$-ラクタ ム類の特徴ある合成法である。

一方，環の縮少へ向から転移もみられる。N-クロル アゼチジン (56) の加溶媒分解はアジリジニウム塩 (57) を経て加水分解を起こし， ベンズアルデヒド (67\%) と エタノールアミン $(36 \%)$ 抽びそのメチルエーテル (39\%)を与える29)。

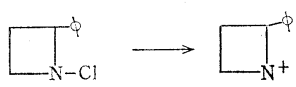

(56)

$$
\begin{aligned}
& \longrightarrow\left(\nabla_{\mathrm{N}-\mathrm{C}_{-\phi}^{\oplus} \underset{{ }^{(57)}}{\longrightarrow}}^{\longrightarrow} D^{\mathrm{N}=\mathrm{CH} \phi}\right) \\
& \phi \mathrm{CHO}+\mathrm{H}_{2} \mathrm{NC}_{2} \mathrm{H}_{4} \mathrm{OH}+\mathrm{H}_{2} \mathrm{NC}_{2} \mathrm{H}_{4} \mathrm{OCH}_{3}
\end{aligned}
$$

ステロイド (58) における例はアジリジンが単離され

(49)

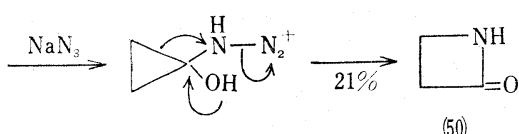

(50)

この反応により縮合シクロプロパン誘導体 (51) から 收率よく $\beta$-ラクタム $(52)$ が合成できる ${ }^{31)}$ これらは

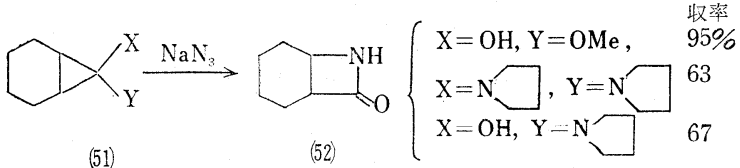

(51)

(52)

一種の Schmidt 反応であるが1b)，ほかのナイトレニウ ムイオン生成反応でも起こすことができる。シクロプロ パノンとアミンとからカルビノールアミン (53) を得て

ている興味ある例である ${ }^{33)}$ 。

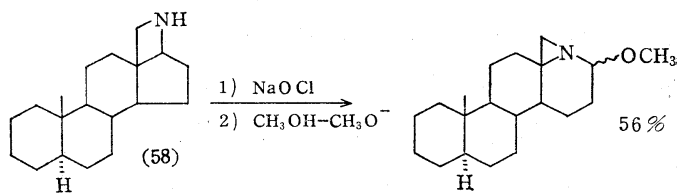

アジリジン環ではインデンから導かれる N-クロルア ジリジン (59) がメタノール中でイソキノリンを与を $ろ^{34)}$ 。この反忘はインデンとジクロルカルベン付加物か<smiles>CNC1NC2c3ccccc3C1c1ccccc12</smiles>

(59)

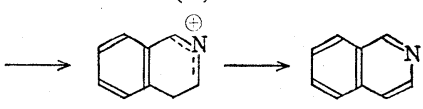


ら 2-クロルナフタリンが生成する反応と対比できる。

$\mathrm{N}$-クロルアジリジンの加溶媒分解の研究は反応機構 について重要な知見を与えた ${ }^{35)}$ 。N-クロルアジリジン (60) の〔3]式に基づくへテロリシスは，N-アジリジ ルカチオン (61) を経て 2-アザアリルカチオン (62) を 与えると期待される([11]式)。この反応を electrocyclic 反応とみなした時 (61) から (62) への開環はシクロプ ロピルカチオンの開環(〔12】式)と同じく disrotatory で あることが Woodward-Hoffmann 則から推定される。<smiles>[R]C1C([R])N1Cl</smiles>

(60)<smiles>[R]C(=[R])N=C([R])[R]</smiles>

(62)

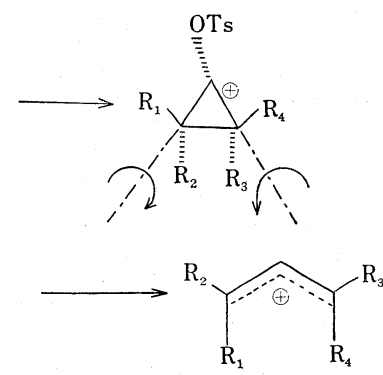

Gassman らはメチル置換 N-クロルアジリジン類が立 体的に安定な $\mathrm{N}-\mathrm{Cl}$ 異性体を与えることに注目し，これ らの加溶媒分解を検討した。最終生成物は（62）の加水 分解で得られるカルボニル化合物である。表 2 亿示す加 溶媒分解の相対速度は disrotatory な開 環から期待され るものである。すなわち，(64）の $\mathrm{N}-\mathrm{Cl}$ 解離は cis の $\mathrm{CH}_{3}$ がより立体障害の大きい方へ回転 (disrotatory) 乙 ながら進行し，(65）は同じ disrotatory の回転で立体障 害の解除の方向へ向からので，(64) と（65）の間に加溶 媒分解速度の差がでてくる。同じ考え方で (68) の著し く早い速度の説明ができる。このように disrotatory な 開環によって相対速度の説明が全く矛盾なく説明される ことは, クロラミンの加溶媒分解が $\mathrm{N}^{\delta+}+. . \mathrm{Cl}^{\delta-}$ 型の遷 移状態を経由する反応であることを見事に証明した。 CNDO/2 によるアジリジルカチオン (61) の 2-アザア
表 2 N-クロルアジリジンの加溶媒分解

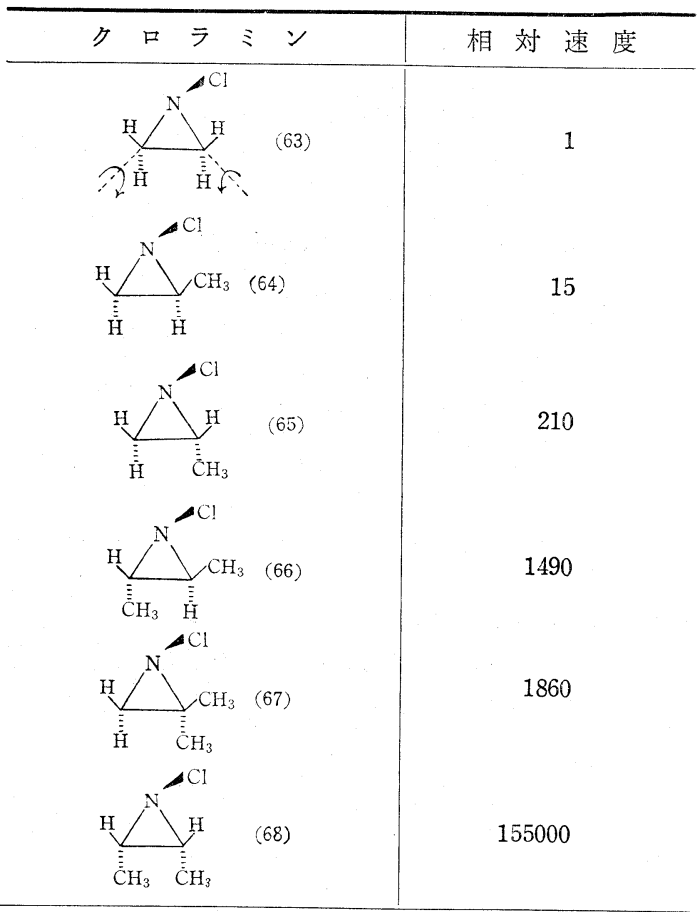

リルカチオン (62) への開環についての計算結果も disrotatory 開環を支持し, また (62) の安定な形は直線で あるといら ${ }^{36)}$ 。

5. 二重結合との反応 Gassman らはナイトレニ ウムイオンとカルボニウムイオンとの類似性の延長とし て,このような反応種はオレフィンとも反応するだろう と考え, 次の不飽和クロラミン (69) の加溶媒分解を行 ない二環性のアミノェーテル $(70 ； 43 \%)$ あるいはアミ ノアルコール $(71 ； 60 \%)$ を得た ${ }^{37}$ 。しかしもら一つ可 能性のある（72）は生成しない。六員の不飽和クロラミ ン (73) は二種の環状化合物 $(74,75)$ を与える ${ }^{3)} 。$ Hobson らも類似の反応を報告している ${ }^{38)}$ 。N-クロル -N-メチルシクロオクテナミン（76）をアセトン中銀塩 存在下に反応させ，環状化合物（77）执よび (78) をそ れぞれ 25 および 11\%の収率で得た。後者の反応はラ

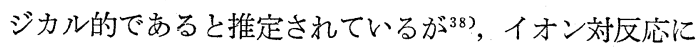
よる機構も考えることができる5 。これらの反応忙合成 反応として今後大いに期待される ${ }^{399}$ 。

この種の反応でもら一つ興味のある反応は 7-クロル7-アザベンゾノルボルナジエン（79 および 80) 9反応 である ${ }^{40)}$ 。syn 異性体 (79) は anti 異性体 (80) より 早くメタノリシスを受け, 図6 のような機構によってエ ノルエーテル（81）を生成する（収率約 40\%)。一方， 
$\sum{\stackrel{\mathrm{Cl}}{\mathrm{N}}-\mathrm{CH}_{3}}_{\mathrm{CH}_{3} \mathrm{OH}}^{\mathrm{Ag}^{+}}$

(69)<smiles>CC(C)(C)C1(C2(C)CC2)CCCC1</smiles><smiles>[R]C1CCC2CCN(C)C12</smiles>

(72)<smiles>CN(C)C1CCC=CCC1</smiles>

(76)<smiles>COC1C2CCN(CC2)C1C</smiles>

(70)<smiles>C[18OH]</smiles><smiles>OCO</smiles><smiles>CN1CCC2CCC1C2O</smiles>

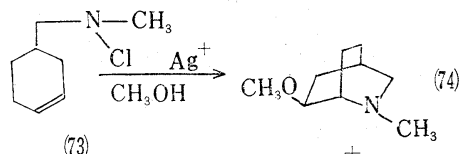

(73)<smiles>CO[C@H]1CC2CCC1CN2C</smiles>

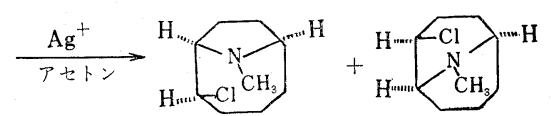

(77)

(78)
図 5

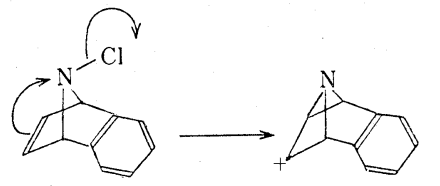<smiles>C1C[Al]N1</smiles>

$\mathrm{CH}_{3} \mathrm{O}^{-}$

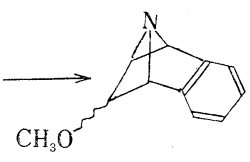<smiles>COCC1C2CCCC(N2)C1OC</smiles>

(81)

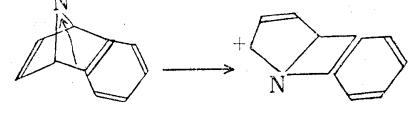

(80)
図 6 anti-(80) 法硝酸銀の存在下の反态でベンゾアゼピン

（82）と推定される化合物を 50\% 収率で与える。

6. フェニル基の転移 上に述べた $(80 \rightarrow 82)$ の反 応はナイトレニウムイオン中心へのフェニル基の転移で ある。この反応は古く 1913 年 Stieglitz によって報告さ れた反応で代表される (〔13]，〔14]式)。ナイトレン

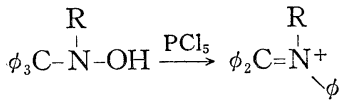

$$
\begin{aligned}
& \stackrel{\mathrm{H}_{2} \mathrm{O}}{\longrightarrow} \phi_{2} \mathrm{C}=\mathrm{O}+\mathrm{R}-\stackrel{\mathrm{H}}{\mathrm{N}}-\phi
\end{aligned}
$$

$$
\stackrel{\mathrm{R}}{\stackrel{1}{\mathrm{~N}}-\mathrm{Cl} \stackrel{\Delta}{\longrightarrow} \phi_{2} \mathrm{C}=\mathrm{O}+\mathrm{R} \dot{\mathrm{N}}^{\mathrm{H}}-\phi}
$$

経由の機構が考えられていたが，〔14]式で $\mathrm{R}=\mathrm{CH}_{3}$ の場 合でも反応が進むというので，ナイトレニウムイオン反 沁に分類される42)。ジフルオルアミン (83) の転移 ${ }^{43)}$ (〔15]式）もフェニル基の転移反応である。

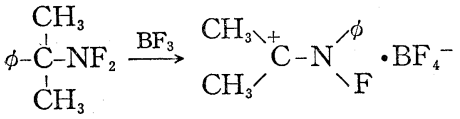

$$
\text { アミノフルオレン (84) からフェナンスリジン (85) }
$$
の生成する反応 ${ }^{44)}$ はアルコキシドによるのでナイトレン 経由とも考えられるが, アジドフルオレン (86) の酸分 解による (85) の合成 ${ }^{45)}$ はナイトレニウムイオン型であ る。
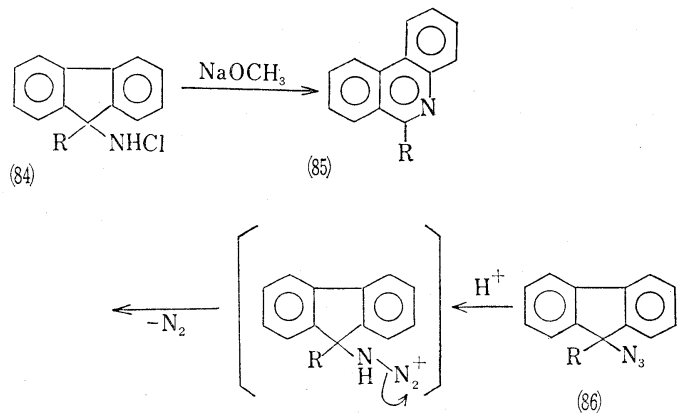

III. アリールナイトレニウムイオン (アニレニウムイオン)

1. N-クロルアニリンの転移Ｎ-クロルコハク酸 
イミドや次要塩素酸塩によるアニリンのクロル化は，ま ず $\mathrm{N}$-クロル化が起こり, 次いで $\mathrm{Cl}$ が環へ転移すると みられている。しかし転移の機構については, $\mathrm{N}-\mathrm{Cl}$ 結 合の開裂の仕方についての問題については, 余り論じら れていなかった。この点についての明解な解答が Gassman らにより行なわれた ${ }^{46,47}$ 。 $\mathrm{N}$-アルキルアニリンを 次亜塩素酸塩または次亜塩素酸ブチルと低温で反応させ ると $\mathrm{N}-$ クロル-N-アルキルアニリン類 (87) が得られ る。(87) をメタノール中で分解するとo-(88) およびpクロルアニリン (89) を与える (〔16]式)。この反応を 銀塩存在下に行なうと（88）拈よび（89）の生成が減少 し, 代わりに $p$-(90) および $o$-アニシジン (91) を与 える。

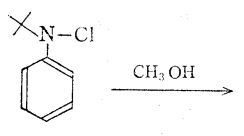

(87)

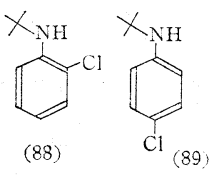

$\mathrm{Ag}^{+}$不在下 $\mathrm{Ag}^{+}$存在下

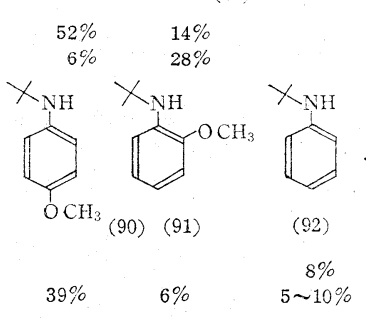

アニシジンの生成は明らかに $\mathrm{CH}_{3} \mathrm{OH}$ よる芳香環の 求核的攻撃を示している。すなわち $\mathrm{N}-\mathrm{Cl}$ 結合が $\mathrm{N}^{+} \ldots$ $\mathrm{Cl}^{-}$の形でヘテロリシスを行ない，ナイトレニウムイオ ン (93) ができ，その共鳴構造である (94) および (95) の陽イオン中心 $\mathrm{CH}_{3} \mathrm{OH}$ が攻撃し，プロトン移動で芳 香化するとo-(90) おょび $p$-アニシジン (91) となる。

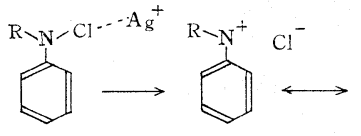

(87)

(93)

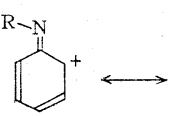

(94)

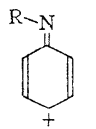

(95)

(91)<smiles>[R]N=C1C=CC=CC1OC</smiles>

図 7

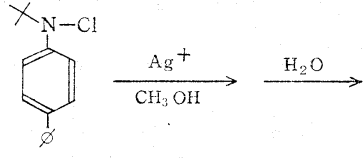

図 $8 \quad$ (97) $62 \%$

いる時は, $\mathrm{Ag}^{+}-\mathrm{CH}_{3} \mathrm{OH}$ の反応により，ジエニルイミ゙ ン（96）を与える。加水分解によりジェノン（97）とな る(図 8)。

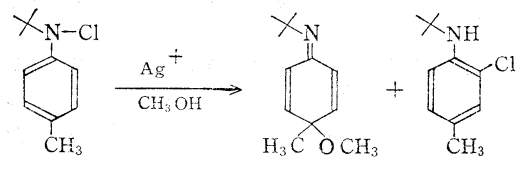

(96) $70 \% \quad 17 \%$

合成的研究に加えて, 速度論的研究の結果は N-Cl 結 合のへテロリシスが $\mathrm{N}^{+} \ldots \mathrm{Cl}^{-}$型であることを証明し

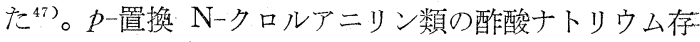
在下のエタノリシス速度は表 3 に示すように著しい置

表 3 N-クロルアニリンの加溶媒分解

$$
\stackrel{0.1 \mathrm{~N} \mathrm{AcOH}-0.1 \mathrm{~N} \mathrm{AcONa}}{\mathrm{C}_{2} \mathrm{H}_{5} \mathrm{OH}}
$$

\begin{tabular}{|c|c|c|c|}
\hline $\mathrm{x}$ & rate, relative & chloride\% & amine $\%$ \\
\hline $\mathrm{CH}_{3}$ & 1800000 & 85 & 1 \\
\hline $\mathrm{F}$ & 44000 & 84 & 8 \\
\hline $\mathrm{H}$ & 6500 & 64 & 16 \\
\hline $\mathrm{Cl}$ & 5200 & 72 & 17 \\
\hline $\mathrm{COOC}_{2} \mathrm{H}_{5}$ & 9 & 78 & 19 \\
\hline $\mathrm{CN}$ & 1 & 64 & 29 \\
\hline
\end{tabular}

換基効果をらけ， $\sigma^{+}$に対し $\rho$ は -6.35 という 值が得られた。この小さな $\rho$ 值は $\mathrm{Cl} \ominus$ の脱離に よるナイトレニウムイオンの生成の証明となり， またのの值から多くの陽イオン電荷が遷移状態 で既に，芳香環に分布していると推定される。こ こで得られた結論は次に述べる Bamberger 転移 などにもあてはめられる。

2. Bamberger 転移 1894 年, Bamber$\operatorname{ger}^{48)}$ はフェニルヒドロキシルアミンが $p$-アミノ フェノールー転移すると一行記載している(〔17〕 式)。气の後約 20 年にわたる彼らのぼう大な研究は半世紀

$$
\mathrm{C}_{6} \mathrm{H}_{5} \mathrm{NHOH} \longrightarrow \mathrm{C}_{6} \mathrm{H}_{4}{ }^{2} \mathrm{OHH}
$$

ジン類の合成に有用である (収率 30〜77\%)。

一方， $p$-位がメチルあるいはフェニルで置換されて

後の現在の研究に決して劣らない成果を挙げている ${ }^{499}$ 。 
汉応は强酸の存在のもとに進み, $p-$ 一 ミノフェノールを主成する。すでに Bamberger らは $\mathrm{Cl}^{-}, \mathrm{HO}^{-}, \mathrm{CH}_{3} \mathrm{O}^{-}$など external な求核㓮の攻撃による生成物を 得ている(〔18]式)。加えて. Bamberger

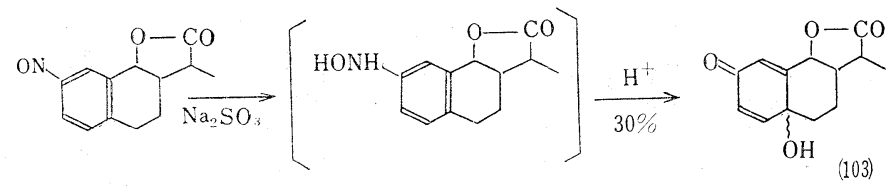
はрーアルキルーフェニルヒドロキシルア<smiles>CCCCOc1ccccc1</smiles>

$\mathrm{X}_{\mathrm{X}=\mathrm{Cl}}^{-}, \mathrm{HO}, \mathrm{CH}_{3} \mathrm{O}^{-\cdots[18]}$

ミンからジエニルイミン (98) を得てい る(〔19]式)。(98) は加水分解によりジ エノン (99) あるいはアルキル基が転移

乙(100)を与える ${ }^{499}$ 。

$$
\underset{\mathrm{OH}^{\ominus}}{\mathrm{NHOH}}
$$<smiles>Nc1ccc(O)c(I)c1</smiles>

これらの事実は, 比較的最近の考え方と併せて ${ }^{50)}$, 酸 礼よる $\mathrm{OH}$ 基の脱離によるナイトレニウムイオン(ア ニレニウムイオン）反応とみることができる（図9）。し かし反応が强酸中で進むことから窒素原子もプロトン化

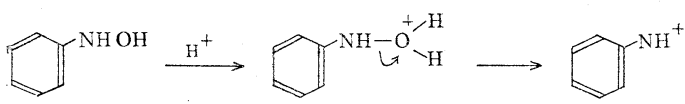

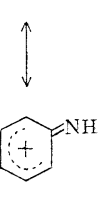

$\mathrm{N}^{\mathrm{NHOH}} \stackrel{\mathrm{H}^{+}}{\longrightarrow}$

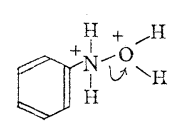

(101)

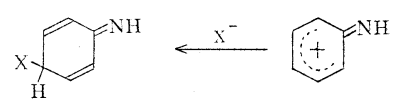

図 9
された (101) から (102)のよらなイオンの生成を経てい るとも考えられる。

[19]式に基くジエノン類の合成は天然物の合成など にも有用であり, 朝比奈らによりヒポサントニルキノー

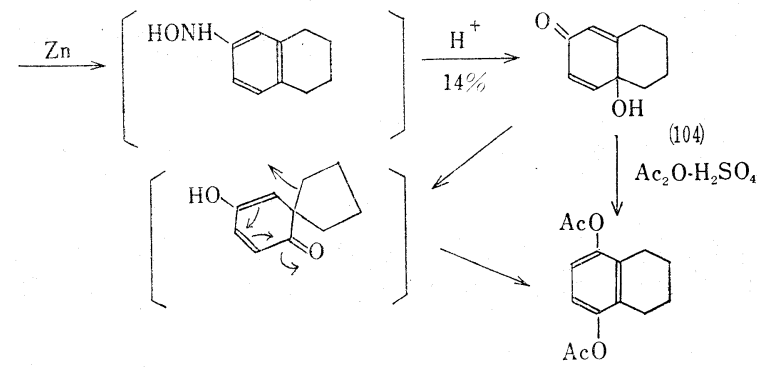

図 10

ル (103)の合成およびテトラリンキノール (104)の合成 に応用されている51) (図 10)。

フェニルヒドロキシルアミン類と全く同じ反応がフェ ニルアジドの酸分解によっても起こる ([20]式 $)^{49) 。 ~}$

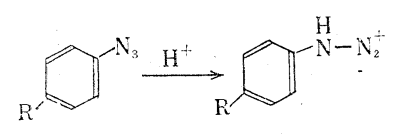

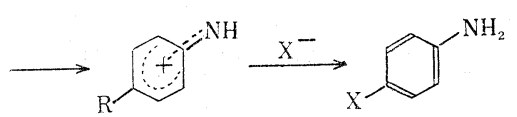

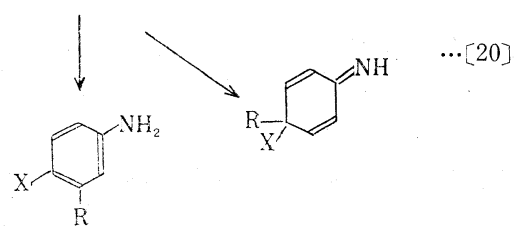

3. N-アシルフェニルヒドロキシルアミン N-ア セチルフェニルヒドロキシルアミンの O-アセチルおよ び O-ベンゾイル体は比較的安定であるが，O-ジクロル アセチル (105a) やO-トリフルオルアセチル体 (105b) はアシル基が 2-および 4-位へ転移し, ${ }^{18} \mathrm{O}$ で標識した 実験では ${ }^{18} \mathrm{O} の 1 / 2$ がフェノールに取り込まれている ので，イオン対 (106) を経由する機構が考えられる52)。

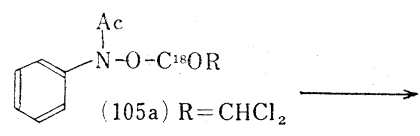

(105b) $\mathrm{R}=\mathrm{CF}_{3}$ 


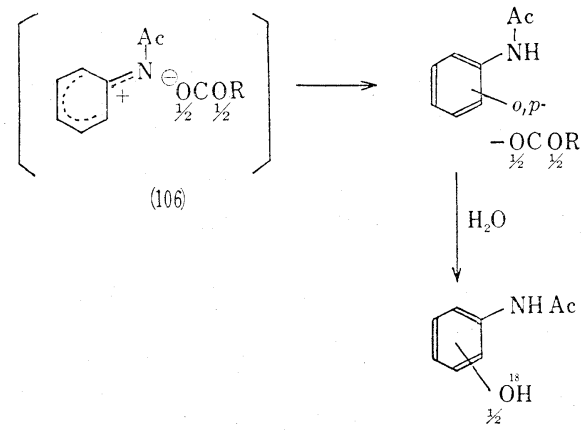

アセチル基の代わりにスルホニル基がついた（107）の 場合では転位によって ${ }^{18} \mathrm{O}$ は均等化されずにフェノー ルに移るので環状の機構が提出されている ${ }^{53)}$ 。

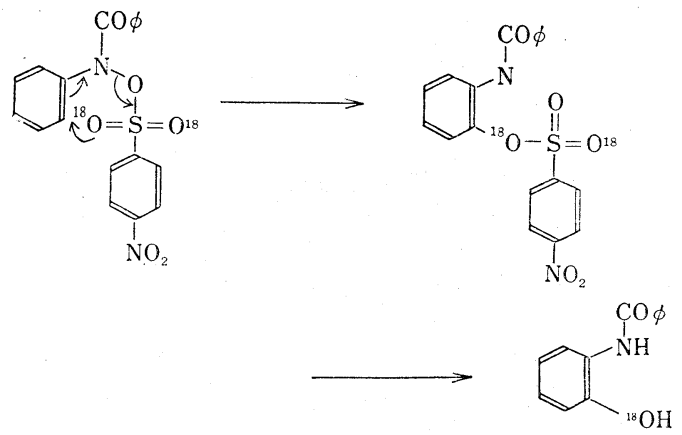

これらと類似しているが，さらにナイトレニウムイオ ンの関与をよく示す反応は分子内アシル誘導体とみられ るオキシインドール (108) の転移である ${ }^{54)}$ 。(108) の p-ニトロベンゾアート (109a) では N-O ヘテロリシス は進行しないが, より強い脱離基であるスルホン酸エス テル (109b) はメタノール中室温下でヘテロリシスを 起こし, 生成した陽イオンヘメタノールが付加して，5メトキシオキシインドール $(110 ; 42 \%)$ および 7-トシ ルオキシオキシインドール $(111 ; 34 \%)$ が生成する。<smiles>O=C1Cc2ccccc2N1O</smiles>

(108)

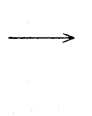

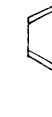

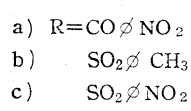

(109)

$$
\downarrow \mathrm{CH}_{3} \mathrm{OH}
$$<smiles>COc1ccc2c(c1)CC(=O)N2</smiles>

(110)<smiles>O=C1Cc2cccc(O)c2N1</smiles>

(111)
図 11

o-転移体 (111) の生成は先の (107) の転移と同様に卜 シルオキシ基のイオン対反応によるとみられるが, (110)
の生成は明らかに $\mathrm{N}-\mathrm{O}$ ヘテロリシスで生成したナイト レニウムイオンの共鳴構造の陽イオン中心へのメタノー ルの求核反応と考えるのが妥当である。この反応はイン ドールアルカロイドの合成などへ応用可能である。

4. ニトロソベンゼンの反応 ニトロソベンゼンの ブロム化はニトロソ基の電子吸引效果にもかかわらず p-位に起こる。ニトロソダイマーの奇与なども考えら れたが反応に誘導期のあること， $\mathrm{HBr}$ により触媒され ること，また酸素や光に影響されないことなどから酸の 関係する求核反応機構が提案されている5 ([21]式)。 ここでプロトンの付加したニトロソベンゼンは N-オキ シアニレニウムイオンとも考えられ，p-位が求核活性 であることになる。

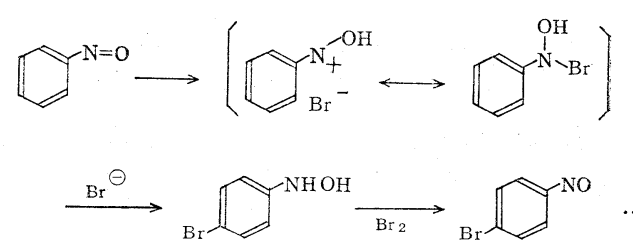

アゾ化合物の酸触媒求核反応も同様とみられる ${ }^{56)}$ 。も ら一つ, ニトロソベンゼンで興味のある反応は三価のリ ン化合物による脱酸素に関連する反応である。一般にこ の種の反応はナイトレンを経るとされている(〔22]式)。

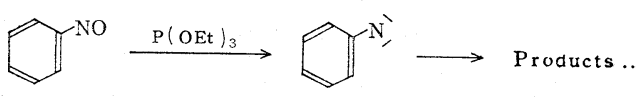

Sundberg はこの反応で一定強度の酸の存在する場合は 全く違う経路で反応することをみつけた ンゼンをメタノールあるいは酢酸を含むエタノール中, $\mathrm{P}(\mathrm{OEt})_{3}$ と反応させると $p$-アニシジンを $49 \%$ の収率 で得る(〔23]式)。エタノールだけの溶媒中では進行し ない。

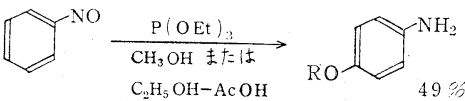

$$
\begin{aligned}
& +\underbrace{\mathrm{NH}_{2}}_{\mathrm{OR}}+\underbrace{\mathrm{NH}_{2}}_{\mathrm{P}(\mathrm{OEt})_{2}}
\end{aligned}
$$

この反応は N-クロラミン転移や Bamberger 転移と 同様にナイトレニウムイオンが関与すると考えられる。 その場合, これがナイトレンのプロトン化により生成し たのか (経路 a)，ホスファイト付加体 (112) から生成 したか（経路 b) の問題がある。フェニルアジドを同条 下に光分解してもアニシジンを与えないことから経路 b がより適当と思われる。 


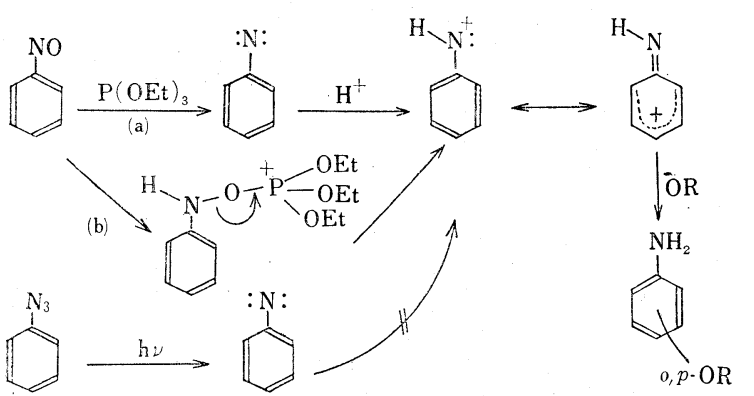

図 12

IV. イモニウムイオン

Beckman 反応は協 奏反応による $\mathrm{N}-\mathrm{O}$ 結合のへテロ リシスであるが，ここでは Beckman 反応の異常反応の 一つともいえるインダノンオキシムの反応を考える。 Lansbury はインダノンオキシム (113) をポリリン酸中 125 $130^{\circ} \mathrm{C}$ に加熱して 70 75\% の収率で $t$-ブチル基 が反応した生成物 (114) および少量の Beckman 転移体 (115 および 116) を得た ${ }^{58)}$ 。

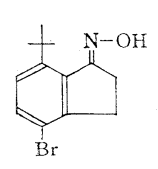

(113)
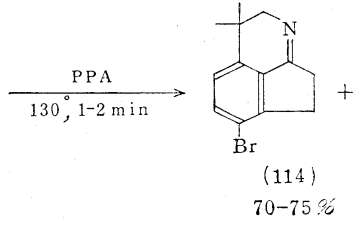

図 13

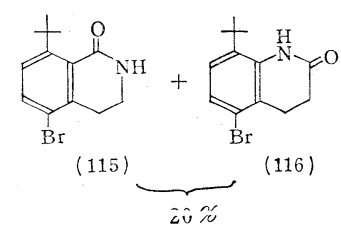

(116)
に近、59)。しかしナイトレン機構は重水素化ポリリン酸 中での反応で重水素化された化合物 (118) が得られない ことから打消すことができ，この反応はナイトレニウム イオン (イモニウムイオン) (119) による C-H 結合へ の挿入反応としてよく説明できる（図 14）。

合成的にも有用とみられるイモニウムイオン反応とし てオキシムと二重結合との反応による環化反応があ $る^{(0)}$ 。シクロペンテニルアセトンオキシム $(121)$ を亜鉛酢酸で加熱するとピロリン誘導体 $(122 ； 30 \%)$ と (123；

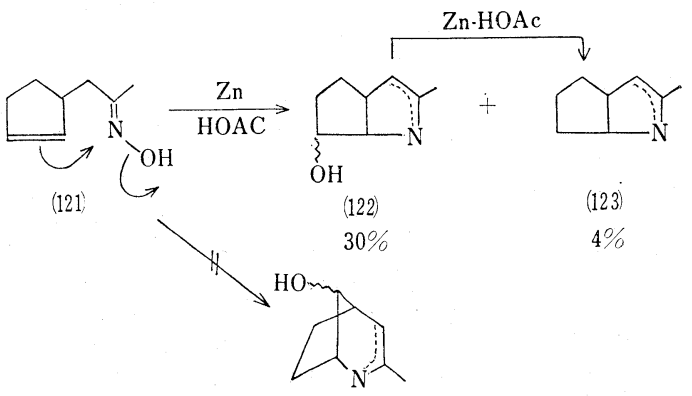

図 15

4\%) が得られる。

\section{V. 一重項および三重項ナイトレ ニウムイオン}

I-IV にあげた反応は $\mathrm{N}-\mathrm{X}$ 結合のへテロ リシスに基ずくことは，生成物分析および反 店速度研究から明らかである。しかし実際に

$\boldsymbol{t}$-ブチル基を重水素化した化合物（117）における同位 体效果 $k_{\mathrm{H}} / k_{\mathrm{D}}=1.4$ といら值は水素の引き抜きの関係す る反応，たとえば Löffler-Freytag 反応での $k_{\mathrm{H}} / k_{\mathrm{D}}=$ 3.54 に較べて小さい值であり, 一重項のカルボエトキ シナイトレンの $\mathrm{C}-\mathrm{H}$ 結合への挿入反応の $k_{\mathrm{H}} / k_{\mathrm{D}}=1.5$
窒素上に陽電荷のあるイオンが存在しうるかどうかにつ いてははっきりしていない。この点で次の実験は重要で ある ${ }^{61)}$ 。

ナイトレニウムイオンは二個の非結合電子をもつ点で カルボニウムイオンと異なる。二個の電子が対をなして<smiles>CC(C)(C)c1ccc(Br)c2c1C(=NO)CC2</smiles>

(117)

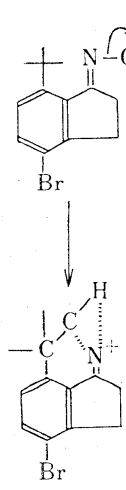

(119)

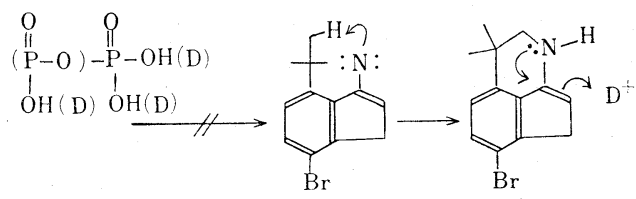

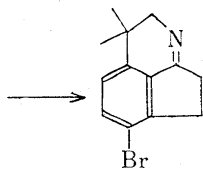

(114)<smiles>[2H]C1Cc2c(Br)ccc3c2C1NCC(C)(C)C3</smiles>

(118) 
いる一重項イオン (124) に対して各々が別の軌道にある 三重項イオン (125) が考えられる。もし一重項イオンが 十分な寿命を持てば, 三重項イオンが生成し, ラジカル 的な水素引き抜き反応によりカチオンラジカル (126) を経て, さらにもら一個の水素を引抜き, 二級アミン (127）を与えるとみられる([24]式)。(126 -127) は Löffler-Freytag 反忘と同じである。実際図 2，3 の反応 にみられるようにクロラミンの加溶媒分解は二級アミン

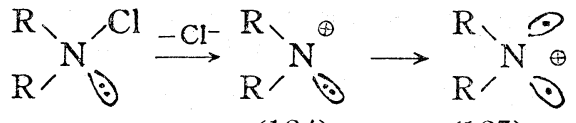

(124)

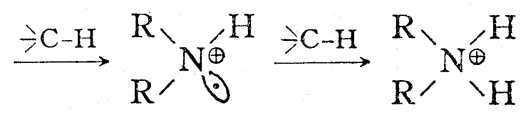

(126)

(127)

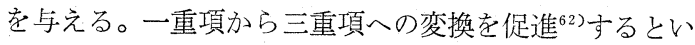
われている重原子を含む溶媒中で, クロラミン (18)の

表 4 クロラミン(18)の加溶媒分解

\begin{tabular}{|c|c|c|c|c|}
\hline $\begin{array}{l}\text { 溶 媒 } \\
1: 1 \mathrm{v} / \mathrm{v}\end{array}$ & (19) & $(20)$ & (21) & $\frac{(21)}{(19)+(20)}$ \\
\hline $\mathrm{CH}_{3} \mathrm{OH}-\mathrm{C}_{6} \mathrm{H}_{12}$ & $56 \%$ & $10 \%$ & $8 \%$ & 8.2 \\
\hline$\underset{p-\mathrm{Br}_{2} \mathrm{C}_{6} \mathrm{H}_{4}}{\mathrm{CH}_{3} \mathrm{OH}}$ & 33 & 10 & 25 & 1.7 \\
\hline $\mathrm{CH}_{3} \mathrm{OH}-\mathrm{CCl}_{4}$ & 13 & $<1$ & 59 & 0.22 \\
\hline $\mathrm{CH}_{3} \mathrm{OH}-\mathrm{CHCl}_{3}$ & 4 & $<1$ & 63 & 0.06 \\
\hline $\mathrm{CH}_{3} \mathrm{OH}-\mathrm{CHBr}$ & $\sim 1$ & $\ll 1$ & 45 & 0.02 \\
\hline$\underset{\mathrm{CH}_{3} \mathrm{OH}}{\mathrm{CH}_{3} \mathrm{OH}-}$ & 59 & 20 & 7 & 11.3 \\
\hline
\end{tabular}

加溶媒分解を行なった結果を表 4 に示す。たとえば $\mathrm{CH}_{3} \mathrm{OH}$ と $\mathrm{CHBr}_{3}$ を $1: 1$ に含む溶媒中では一重項イ オンによる生成物である（19）および（20）の生成が減 少し，〔24】式に基ずく反応で三重項イオンからの二級 アミン (21) が飛躍的に増加する。これが溶媒の極性効 果でないことは $\mathrm{CH}_{3} \mathrm{OH}-\mathrm{C}_{6} \mathrm{H}_{12}$ 中での反応との比較か ら明らかである。

この実験結果は, クロラミンの加溶媒分解により一重 項 $\rightarrow$ 三重項の変換のために十分な寿命をもつ一重項ナイ トレニウムイオンが生成していること, さらに三重項イ オンの存在も示唆する。

$\mathrm{N}-$ クロルアニリンの転移(〔16]式)でも原料のアニリ ンが生成する（表 3） ${ }^{47}$ 。電子吸引基をもち, 陽電荷が窒 素原子上により多く, よりナイトレニウムイオン性が強 いとみられる場合に原料アニリンが増えることは, 三重 項イオンの関与している可能性を示す。同じくEdwards らによる環化反応 $(5 \rightarrow 6)$ においても三重項イオンによ
る反応と考えることもできる(図 1 ${ }^{13)}$ 。

一方, Lansbury らによるインモニウムイオン反忘(図 13,14) における C-N 結合の生成は一重項イオンの C$\mathrm{H}$ 結合への插入反応とみられている

分子軌導法による ${ }^{+} \mathrm{NH}_{2}$ イオンの計算では一重項よ 三重項イオンとのエネルギ一差が $45 \mathrm{kcal} / \mathrm{mol}$ と計算さ れている63)。

\section{VI. 発がんとナイトレニウムイオン}

これまで多くのナイトレニウムイオンの関係する反応 をあげてきたが，合成や反応機構の研究とは別に，発が ん物質の研究が特にアニレニウムイオンの新しい反応の 可能性を示してくれた。

強い発がん物質として芳香族のニトロあるいはアミノ 化合物（たとえば 128～131） は生体内でいずれも対応 するヒドロキシルアミン $(132 \sim 135)$ あるいはその誘導 体へ酸化ないし還元されてから生体物質と反応して発が んの引金となることがわかっている。その中でも Miller の研究は示唆に富む ${ }^{64)}$ (図 16)。

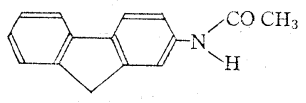

(128)

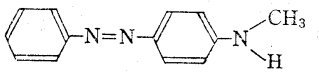

(129)<smiles>Nc1ccc2ccccc2c1</smiles>

(130)<smiles>O=[N+]([O-])c1cc[n+]([O-])c2ccccc12</smiles>

(131)

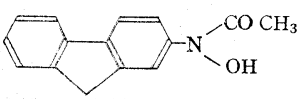

(132)

(133)<smiles>ONc1ccc2ccccc2c1</smiles>

(134)<smiles>[O-][n+]1ccc(NO)c2ccccc21</smiles>

(135)

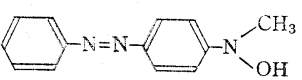

図 16

最も強い発がん物質の一つであるアセチルアミノフル オレン (128) は生体内で酸化されて, N-アセチルヒド ロキシルアミン (132) あるいはその O-アシル誘導体と なって蛋白成分や核酸と反応する。図17 は(132) とメチ オニルグリシンおよび生体内での蛋白との反応を示す。 (132)：は体内で O-アセチル化（またはリン酸化，スル ホン化)されてのちに反応しているとみられるが, 代謝物 の中から 3-メチルチオフルオレン (136) が同定される。 (132) とメチオニルグリシンとからを(136) が生成する がこの反応は III-3 に述べたようなアシルアニレニウ ムイオン (137) からスルホニウム塩 (138) を経てできた 


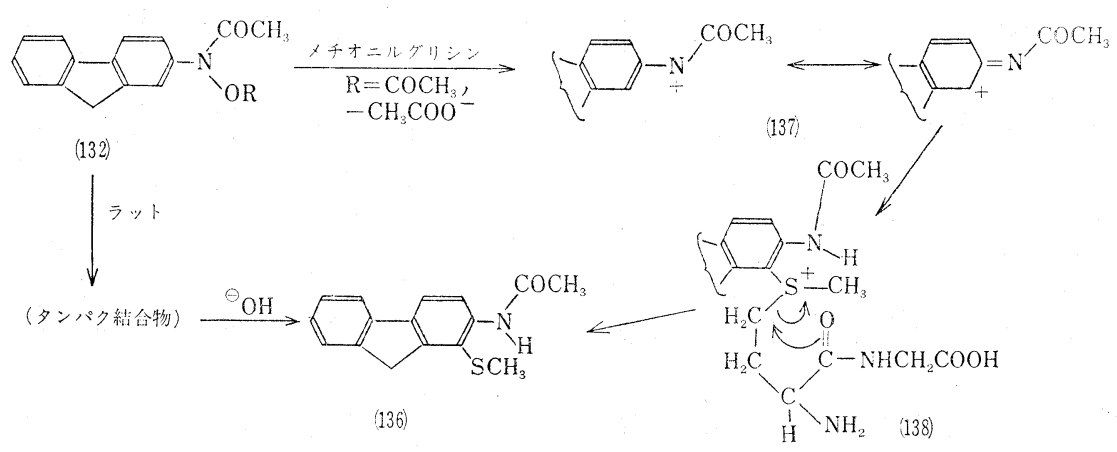

図 17

と推定される。同種の反応生成物はアミノアン゙ベンゼン (133) の代謝物からも得られる。

N-クロルアニリンとスルフィドとの反応は，これら の発がん物質の反応と関連する。N-クロルアニリン (87) とジメチルスルフィドは安定なアザスルホニウム 塩 (139) を形成するが，これを DMF 中 $100^{\circ} \mathrm{C}$ 亿加熱 するとo-および $p$ オチルチオアニリン $(140,141)$ が得 られる（図 18）。この反応は N-S 結合のヘテロリシス

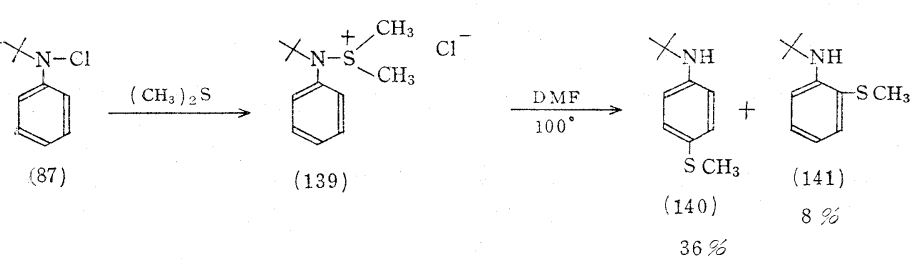

図 18
で生成したアニレニウムイオンとジメチルフルフィドと の反応として容易に説明でき，(132）の発がん反応と類 似する。

ヒドロキシアミノアゾベンゼン (133) とチロシンとの 反応および (132) と核酸との反庄示す（园 19,20）。 (133)のO-ベンゾアートとチロシンは容易に反応し C-C 結合が形成された (142) と C-N 結合が形成された(143) とを与えるが，同一のものは (129) のラットにおける代 謝物からも同定される。一方 (132) 々 核酸との反応法 C-N 結合が形成され た(144)を与える。この(144) も生体代 謝物の中に同定されるものである。以 上の反忘はアニレニウムイオンと求核 試薬としての芳香環との反応であり， 次のように単純化されらる(〔25]式)。

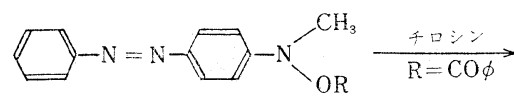

(133)

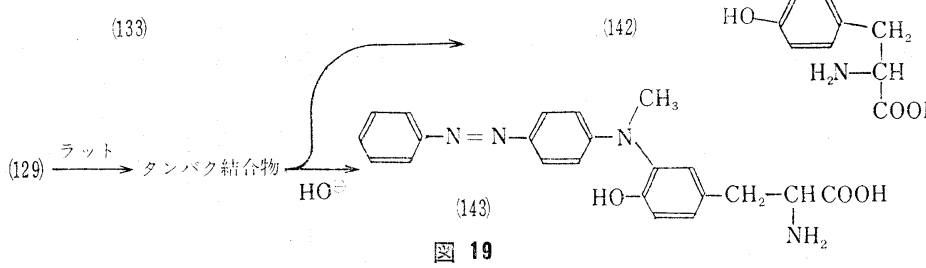

图 19<smiles>CC=CC=CC</smiles>

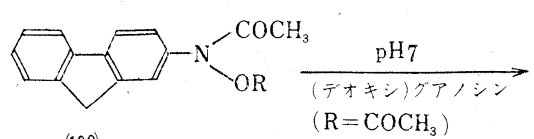

(132)

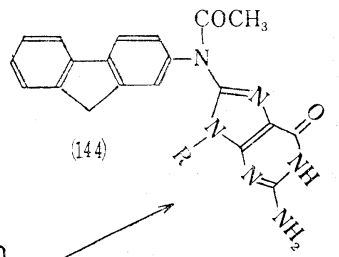

$\left(\mathrm{H}_{2} \mathrm{O}\right)$

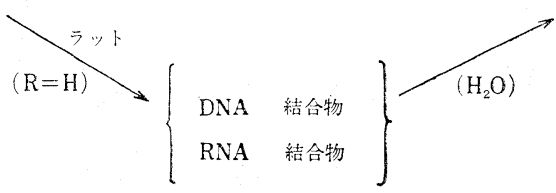

図 20 


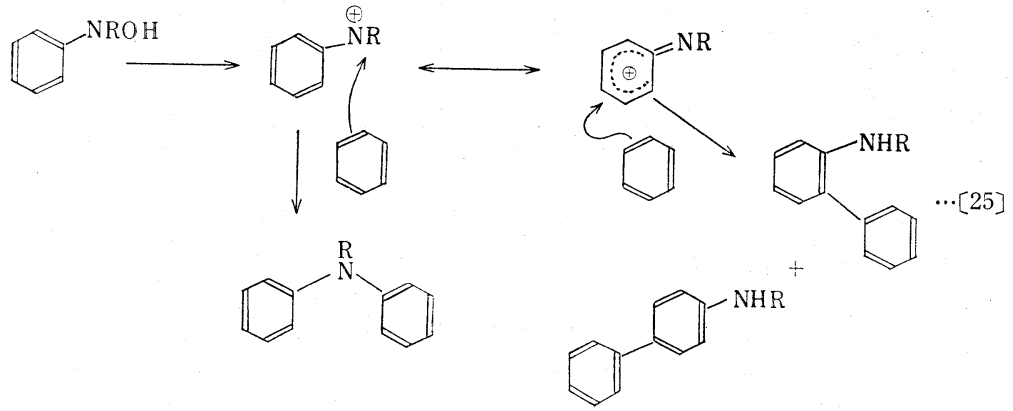

どにも，N-X 結 合のヘテロリシ スといら観点から議論する余地が ある。

$\mathrm{N}-\mathrm{X}$ 結合の反応 (ヘテロリシ ス）が読者にとって，より身近な ものになり, 何かのお役に立つこ とがあれば，筆者の喜びである。 文中には箨者の浅薄な考えのため の無理な解釈, 説明不足が多数み

実際, フェニルヒドロキシルアミンは四フッ化ホウ素 酸の存在下に芳香族化合物と反応し，15 46\% の收率 で 2-および 4-ビフェニルアミン (145) を与える65)。

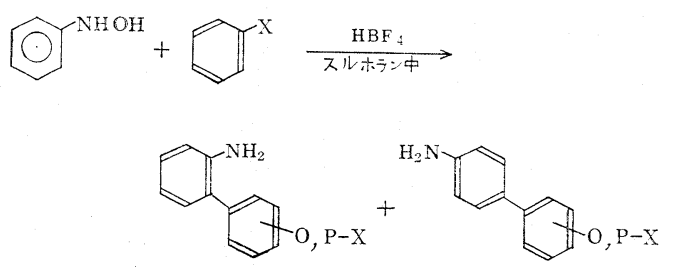

(145)

筆者らは $(133 \rightarrow 142)$ あるいは $(132 \rightarrow 144)$ と類似す る反応を合成的に行なわせようとした結果，フェニルヒ ドロキシルアミン類とベンゼン類をトリフルオル酢酸の 存在下に反応させて, かなりの收率でジフェニルアミン 類を得るのに成功した ${ }^{66}$ (図 21)。この反忘は窒素上で

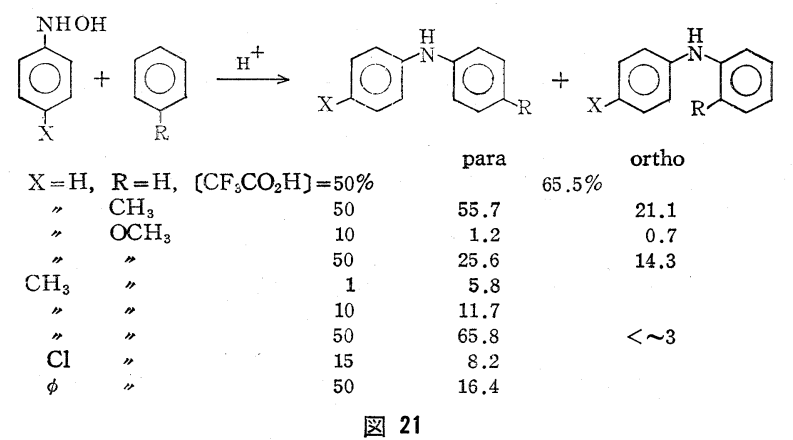

の反応の数少い例であり，〔25】式に基ずく反応とみら れるが，機構についてはなお検討の必要がある。

\section{あとがき}

以上ナイトレニウムイオンに関係のあるとみられる反 応堂種々列挙したが，これらは基本的な反応としてのほ か, 合成化学への応用にも多分の可能性を持っていると 思われ，今後の応用・発展を期待したい ${ }^{67) 。 ~}$

アゾキシベンゼンの Wallash 転移, ニトラミンの転 移, ベンジジン転移や複素環 N-オキシドの転移反応な
られると思うが，ご叱正を請うしだいである。

(昭和 48 年 1 月 9 日受理)

\section{文献}

1a) P.A.S. Smith, "Open Chain Nitrogen Compounds"

b) P.A.S. Smith, "Molecular Rearrangement" P. deMayo 編, Chapter 8, p.457

2) R.A. Abramovitch, B.A. Davis, Chem. Rev. 64149 (1964)

3) P.G. Gassman, Accounts, Chem Res. 326 (1970)

4) W.T. Huntress, D.D. Elleman, J. Am. Chem. Soc. 928565 (1970)

5) P. Kovacic, M.K. Lowery, K.W. Field, Chem. Rev. 70639 (1970)

6) W. Theilacker, E. Wegner, Angew. Chem. 72 127 (1960); E. Colton, M.M. Jones, J. Chem. Educ. 34485 (1955)

7) J. Meinwald, P.G. Gassman, E.G. Miller, J* Am. Chem. Soc. 814751 (1959)

8) 田村, 南川, 須本, 三木, 松下, 北, 池田, 複 素環化学討論会 5113 (1972)

9) H. Bock, K.L. Kompa, Z. Anorg. Allg. Chem. 332238 (1964)

10) R. Ohme, E. Schmitz, P. Dolge, Chem. Ber. 992104 (1966)

11) H. Bock, K.L. Kompa, Chem. Ber. 99 1347, 1357, 1361 (1966)

12) V. Prelog, J.G. Traynhan, "Molecular Rearrangement” P. deMayo 編, p. 617

13) O.E. Edwards, D. Vocelle, J.W. ApSimon, F. Haque, J. Am. Chem. Soc. 87678 (1965)

14) P.G. Gassman, J.E. Trent, Chem. Commun. 1972854

15) G. Adams, K. Schreiber, Angew. Chem. 76 752 (1964)

16) T.A. Kling, R.E. White, P. Kovacic, J. Am. Chem. Soc. 947416 (1972); T.A. Kling, M.B. Nazareno, P. Kovacic, ibid. 942157 (1972)

17) K.W. Sherk, A.G Houpt, A.W. Browne, J. Am. Chem. Soc. 62329 (1940); J.H. Boyer, F.C. Canter, J. Hamer, R.K. Putney, ibid. 78 325 (1956) 
18) P.G. Gassman, B.L. Fox, Chem. Commun. 1966 153; Idem. J. Am. Chem. Soc. 89338 (1967)

19) P.G. Gassman, R.L. Cryberg, J. Am. Chem. Soc. 901355 (1968); Idem, ibid. 912047 (1969)

20) P.G. Gassman, K. Shudo, R.L. Cryberg, A. Battiste, Tetrahedron Lett. 1972875

21) A. Colter, E.C. Friedrich, N.J. Holness, S. Winstein, J. Am. Chem. Soc. 87378 (1965)

22）この反応では（29）および（30）の収率のばらつ きが大きく (29) $\rightleftarrows(30)$ のような異性化の可能性 もある ${ }^{20)}$ 。

23) J.M. Biehler, J.P. Fleury, Tetrahedron 27 3171 (1971)

24) P.G. Gassman, G.D. Hartman, K. Shudo, Central Regional ACS Meeting. (1970) p. 55.

25) P.G. Gassman, K. Shudo, J. Am. Chem. Soc. 935899 (1971)

26) P. Kovacic, M.L. Lowery, P.D. Roskos, Tetrahedron 26529 (1970)

27) P.Kovacic, J.H. Liu, P.D. Roskos, E.M. Levi, Chem. Commun. 1970 1034; P. Kovacic, J.H. Liu, E.M. Levi, P.D. Roskos, J. Am. Chem. Soc. 935801 (1971)

27a) R.D. Fisher, T.D. Bogard, P. Kovacic, J. Am. Chem. Soc. 947599 (1972)

28) P.G. Gassman, A. Carrasquillo, Chem. Commun. 1965495

29) Idem. Tetrahedron Lett. 1971109

30) H.H. Wasserman, R.E. Cochoy, M.S. Baird, J. Am. Chem. Soc. 912375 (1969)

31) H.H. Wasserman, M.S. Baird, Tetrahedron Lett. 19713721

32) H.H. Wasserman, H.W. Adickes, O.E. Ochoa, J. Am. Chem. Soc. 935586 (1971)

33) C. Benezra, X. Lusinchi, Can. J. Chem. 47 1547 (1969)

34) D.C. Horwell, C.W. Rees, Chem. Commun. 19691428

35) P.G. Gassman, D.K. Dygos, J. Am. Chem. Soc. 911543 (1969)

36) R.G. Weiss, Tetrahebron 27271 (1971)

37) P.G. Gassman, F. Hoyda, D.K. Dygos, J. Am. Chem. Soc. 902716 (1968)

38) J.D. Hobson, W.D. Riddell, Chem. Commun. 19681178

39) $c f$. W. Nagata, S. Hirai, Kawata, T. Aoki, J. Am. Chem. Soc. 895045 (1967)

40) V. Rautenstrauch, Chem. Commun. 19691122
41) J. Stieglitz, P.N. Leech, Ber. 462147 (1913)

42) R.T. Conley, H. Brandman, cited in ref. 3.

43) T.E. Stevens, J. Org. Chem. 332664 (1968)

44) L.A. Pinck, H.E. Hilbert, J. Am. Chem. Soc. 598 (1937)

45) M.M. Coombs, J. Chem. Soc. 19584200

46) P.G. Gassman, G.A. Campbell, R.E. Fredrick, J. Am. Chem. Soc. 943884 (1972)

47) P.G. Gassman, G.A. Campbell, J. Am. Chem. Soc. 943891 (1972)

48) E. Bamberger, Ber. 271347 (1894)

49) Idem. Ann. 424233 (1921)

50) E.D. Hughes, C.K. Ingold, Quart. Rev. 645 (1952) ; Y. Yukawa, 日化 71603 (1950); M.J. S. Dewar, "Molecular Rearrangements" Vol. 1, Chapter 5, p. 308

51) Y. Asahina, T. Momose, Ber. 711421 (1938)

52) J.R. Cox, M.F. Dunn, 152 nd ACS Meeting, p. S 162 (1966)

53) G.T. Tisue, M. Grassman, W. Lwowski, Tetrahedron 24999 (1968)

54) P.G. Gassman, G.A. Campbell. Chem. Commun. 19711437

55) P.W. Robertson, T.R. Hitchings, G.M. Will, J. Chem. Soc. 1950808

56) J.F. Bunnett, E. Buncel, K.V. Nahabedian, J. Am. Chem. Soc. 844136 (1962) ; J.F. Bunnett, E. Buncel, ibid. 834136 (1961); Z.J. Allan, Coll. Czeck, Chem. Com. 3061 (1965)

57) R.J. Sundberg, R.H. Smith, J. Org. Chem. 36 295 (1971)

58) P.T. Lansbury J.G. Colson, N.R. Mancuso, J. Am. Chem. Soc. 865225 (1964); P.T. Lansbury "Nitrene" Lwowsky 編 (1970) Interscience

59) P.T. Lansbury, P.C. Briggs, Chem. Commun. 19691152

60) R. Griot, T. Wagner-Jaurreg, Helv. Chim. Acta 41867 (1958); 42 121, 605 (1959)

61) P.G. Gassman, R.L. Cryberg, J. Am. Chem. Soc. 915176 (1969)

62) A.G. Anastassiou, idid. 882322 (1966)

63) S.T. Lee, K. Morokuma, J. Am. Chem. Soc. 936863 (1971)

64) J.A. Miller, Can. Research 30559 (1970)

65) J.H. Parish, M.C. Whiting, J. Chem. Soc. 19644713

66) 岡本, 首藤, 未発表

67) 脱稿後の新しい文献 : C. A. Wilkie, D.R. Dimmel, J. Am. Chem. Soc. 948600 (1972);P.G. Gassman et al., idid. 95 449, 588,612 (1973) 